\title{
Pengaruh Penambahan Serpihan Aluminium Sebagai Bahan Parsial Semen Terhadap Kuat Tekan dan Kuat Tarik Belah Beton
}

\author{
Monica Reigita Y. ${ }^{1}$., Agustinus Agus S. ${ }^{2}$ \\ ${ }^{1}$ Program Studi Teknik Sipil, Universitas Pembangunan Jaya \\ monica.reigitayahya@student.upj.ac.id \\ ${ }^{2}$ Program Studi Teknik Sipil, Universitas Pembangunan Jaya \\ agustinus@upj.ac.id
}

\begin{abstract}
This study aims to determine the mechanic properties of concrete with aluminium scrap as partial material of cement. The mechanical properties of concrete that are used as parameters are comppresive strength and tensile splitting strength. The sample used in this study is cylindrical concrete specimens with diameter $150 \mathrm{~mm}$ and height $300 \mathrm{~mm}$. Concrete mixtures that given partial materials of aluminium scrap vary from $0 \%, 5 \%, 7.5 \%$ and $10 \%$. The result of this study shows that the increasing percentage of aluminium scrap makes the spesific gravity decreased. Meanwhile, the compressive strength and tensile splitting strength also decreased.
\end{abstract}

Keywords : concrete, alumunium scrap, compressive strength, tensile splitting strength

\begin{abstract}
Abstrak : Penelitian ini bertujuan untuk mengetahui sifat mekanik dari beton dengan serpihan aluminium sebagai bahan parsial semen. Sifat mekanik beton yang dijadikan parameter adalah kuat tekan dan kuat tarik belah beton. Sampel pada penelitian ini berbentuk silinder beton dengan ukuran diameter $150 \mathrm{~mm}$ dan tinggi $300 \mathrm{~mm}$. Campuran beton yang diberikan bahan parsial serpihan aluminium bervariasi mulai dari $0 \%, 5 \%, 7.5 \%$ dan $10 \%$. Hasil pengujian menunjukan bahwa semakin bertambahnya persentase serpihan aluminium, maka berat jenis benda uji semakin menurun, tetapi belum termasuk kategori beton ringan. Sedangkan pengaruhnya terhadap kuat tekan dan kuat tarik belah beton juga menurun.
\end{abstract}

Kata Kunci : beton, serpihan aluminium, kuat tekan, kuat tarik belah

\section{PENDAHULUAN}

Pembangunan dalam bidang konstruksi terus berkembang dengan pesat seiring berjalannya waktu dan berkembangnya teknologi. Pertambahan jumlah penduduk yang signifikan juga menjadi alasan besar pembangunan terus terjadi. Beton merupakan salah satu material yang sudah lama digunakan di dunia konstruksi dan dapat dimanfaatkan dalam banyak hal. Kebanyakan material beton digunakan sebagai struktur dalam konstruksi, misalnya untuk kolom, balok, pelat atau elemen struktur lainnya. Banyaknya penggunaan beton dalam dunia konstruksi membuat adanya upaya untuk terus menciptakan mutu beton yang baik.
Kebutuhan akan semen sebagai bahan pengikat tentunya akan terus meningkat seiring dengan maraknya pembangunan konstruksi. Hal ini kemudian menimbulkan alasan untuk mencari bahan baru yang dapat menggantikan fungsi semen, tetapi tetap ekonomis dan juga ramah lingkungan. Banyak bahan sisa atau limbah dari suatu pekerjaan yang dapat dimanfaatkan menjadi alternatif pengganti semen. Salah satu bahan yang dapat digunakan sebagai pengganti parsial semen ialah serbuk aluminium yang merupakan limbah dari proses pemotongan alumunium.

Aluminium merupakan salah satu jenis logam yang sukar mengalami korosi, 
sehingga aluminium banyak dimanfaatkan dalam kehidupan manusia.

Dalam penelitian ini, akan diteliti pengaruh serbuk alumunium terhadap mutu beton dengan parameter pengukuran kuat tekan dan kuat tarik belah beton.

\section{KAJIAN PUSTAKA Beton}

Beton adalah campuran antara semen, agregat halus, agregat kasar, dan air dengan atau tanpa bahan tambah membentuk massa padat ${ }^{[1]}$. Pencampuran material-material tersebut akan menimbulkan reaksi kimia antara semen dan air sehingga campuran tersebut akan mengeras.

Agregat dalam beton berfungsi sebagai pengisi rongga pada beton, dimana jumlahnya berkisar antara $70-80 \%$ dari total volume beton. Kualitas dari agregat akan berpengaruh terhadap sifat-sifat beton yang dihasilkan, seperti kuat tekan, kuat tarik belah, berat jenis dan sifat lainnya. Air pada beton berfungsi untuk membentuk terjadinya reaksi kimiawi pada semen, sehingga terjadi pengikatan pada campuran beton.

Semen merupakan bahan perekat pada campuran beton, dimana berfungsi untuk menyatukan agregat halus dan agregat kasar menjadi satu kesatuan. Semen Portland memiliki komposisi kimia yang beragam, tetapi bahan utama yang digunakan dalam pembuatan semen adalah kapur, silika, alumina, dan besi oksida.

Pencampuran semen dengan air menimbulkan reaksi kimia yang menyebabkan adanya ikatan dan pengerasan. Empat senyawa kimia yang memiliki peran dalam proses kimia tersebut adalah $\mathrm{C}_{3} \mathrm{~S}, \mathrm{C}_{2} \mathrm{~S}, \mathrm{C}_{3} \mathrm{~A}$, dan $\mathrm{C}_{4} \mathrm{AF}$.

- Trikalsium Silikat $\left(\mathrm{C}_{3} \mathrm{~S}\right.$ atau $3 \mathrm{CaOSiO}_{2}$ ), senyawa ini akan mengeras dengan cara melepaskan panas. Jumlah reaksi ikatan dengan senyawa ini berperan dalam menentukan kekuatan beton pada umur awal, yaitu 14 hari pertama.
- Dikalsium Silikat $\left(\mathrm{C}_{2} \mathrm{~S}\right.$ atau $2 \mathrm{CaOSiO}_{2}$ ), senyawa ini berpengaruh dalam meningkatkan kekuatan dalam umur beton 14 sampai 28 hari. Semen yang memiliki senyawa $\mathrm{C}_{2} \mathrm{~S}$ dalam jumlah banyak akan memiliki ketahanan tergadap agresi kimia.

- Trikalsium Alumina $\left(\mathrm{C}_{3} \mathrm{~A}\right.$ atau $3 \mathrm{CaOAl}_{2} \mathrm{O}_{3}$ ), senyawa ini berperan dalam pengerasan awal dan mengalami hidrasi yang sangat cepat, tetapi senyawa ini membuat semen kurang tahan terhadap agresi kimia dan dapat menyebabkan retak apabila terjadi perubahan volume.

- Tetrakalsium Aluminoferit $\left(\mathrm{C}_{4} \mathrm{AF}\right.$ atau $4 \mathrm{CaOAl}_{2} \mathrm{O}_{3} \mathrm{Fe}_{2} \mathrm{O}_{3}$ ), senyawa ini tidak memberikan pengaruh yang penting terhadap kekuatan dan sifat semen.

Tabel 1. Komposisi Kimia dan Kadarnya

\begin{tabular}{cc}
\multicolumn{2}{c}{ Dalam Semen } \\
\hline Oksida & Kadar (\%) \\
\hline $\mathrm{CaO}$ & $60-67$ \\
\hline $\mathrm{SiO}_{2}$ & $17-25$ \\
\hline $\mathrm{Al}_{2} \mathrm{O}_{3}$ & $3.0-8.0$ \\
\hline $\mathrm{Fe}_{2} \mathrm{O}_{3}$ & $0.5-6.0$ \\
\hline $\mathrm{MgO}$ & $0.1-4.0$ \\
\hline Alkali $\left(\mathrm{K}_{2} \mathrm{O}, \mathrm{Na}_{2} \mathrm{O}\right)$ & $0.4-1.3$ \\
\hline $\mathrm{SO}_{3}$ & $1.3-3.0$ \\
\hline
\end{tabular}

\section{Limbah Aluminium}

Limbah aluminium yang akan digunakan dalam penelitian ini merupakan limbah yang dihasilkan dari pemotongan bahan aluminium seperti kusen aluminium. Pemotongan bahan aluminium tersebut menghasilkan beragam ukuran limbah, mulai dari potongan-potongan besar hingga serbuk-serbuk halus. Dalam penelitian ini, bahan aluminium yang digunakan berupa serpihan-serpihan halus, seperti pada Gambar 1. Aluminium sendiri merupakan salah satu bahan kimia yang digunakan dalam pembuatan semen, dalam bentuk Aluminium Oksida atau Alumina (A12O3) dengan kadar berkisar $3-8 \%$. Alumina merupakan salah satu material yang memiliki sifat insulator panas dan listrik yang baik. Aluminium merupakan bahan 
yang tidak mudah terkena karat, sehingga dapat digunakan sebagai salah satu bahan campuran pada semen.

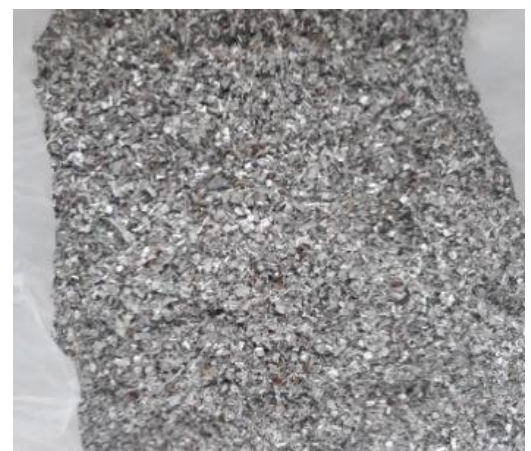

Gambar 1. Limbah Aluminium

\section{Kuat Tekan}

Kuat tekan beton adalah besarnya kuat tekan maksimum yang dipikul oleh beton per satuan luas ${ }^{[3]}$. Pengujian kuat tekan beton dilakukan dengan alat compressing testing machine (CTM) dengan meletakkan benda uji berbentuk silinder (ukuran diameter $150 \mathrm{~mm}$, tinggi $300 \mathrm{~mm}$ ) secara tegak lurus dan memberikan beban tekan bertingkat sampai benda uji runtuh. Pada pengujian ini diperoleh beban maksimum yang dapat ditahan oleh benda uji hingga hancur. Kuat tekan beton kemudian dapat dihitung dengan membagi beban maksimum dengan luas permukaan silinder benda uji, atau dapat dituliskan secara matematis sebagai:

$$
f_{c}^{\prime}=\frac{P}{A}
$$

dengan :

$f^{\prime}{ }^{\prime} \quad=$ kuat tekan $(\mathrm{MPa})$

$P \quad=$ beban tekan maksimum, Newton

$A \quad=$ luas penampang silinder beton

$$
\left(\frac{1}{4} \pi D^{2}\right), \mathrm{mm}
$$

Berdasarkan pengujian yang telah dilakukan, maka dapat dilihat persentase kuat tekan beton pada masing-masing benda uji. Sesuai dengan Peraturan Beton Indonesia 1971, terdapat standar kuat tekan beton sesuai dengan usia betonnya. Standar tersebut dapat dilihat pada pada Tabel 2 berikut ini.
Tabel 2. Korelasi Usia Beton dengan Kuat Tekan Beton ${ }^{[4]}$

\begin{tabular}{cc}
\hline $\begin{array}{c}\text { Usia Beton } \\
\text { (Hari) }\end{array}$ & $\begin{array}{c}\text { Kuat Tekan } \\
\text { Beton } \\
(\boldsymbol{\%})\end{array}$ \\
\hline 3 & 40 \\
\hline 7 & 65 \\
\hline 14 & 88 \\
\hline 21 & 95 \\
\hline 28 & 100 \\
\hline 56 & 112,4 \\
\hline
\end{tabular}

\section{Kuat Tarik Belah}

Kuat tarik belah beton adalah nilai kuat tarik tidak langsung dari benda uji beton yang berbentuk silinder, yang diperoleh dari pembebanan benda uji tersebut yang diletakkan secara mendatar, sejajar dengan permukaan meja penekan mesin uji tekan ${ }^{[5]}$. Kuat tarik belah diperoleh dengan metode pengujian kuat tarik belah menggunakan universal testing machine (UTM). Pengujian ini dilakukan dengan meletakkan benda uji pada arah memanjang di atas alat uji, kemudian benda uji diberikan beban tekan secara merata pada arah tegak dari pada pada seluruh panjang silinder. Pada saat kuat tarik terlampaui, maka benda uji akan terbelah menjadi dua bagian dari ujung ke ujung. Perhitungan kuat tarik belah dari benda uji ditentukan dengan rumus berikut:

$$
f_{c t}=\frac{2 P}{\pi L D}
$$

dengan:

$f_{c t} \quad=$ kuat tarik - belah $(\mathrm{MPa})$

$P \quad=$ beban maksimum $(\mathrm{N})$

$L \quad=$ panjang benda uji $(\mathrm{mm})$

$D \quad=$ diameter benda uji $(\mathrm{mm})$

Hubungan kuat tarik belah beton dengan kuat tekan beton dapat diketahui dengan persamaan berikut ${ }^{[8]}$ :

$f_{t}=0,56 f_{c}^{\prime 0,5}$

\section{Studi Terdahulu}

Zainudin $^{[6]}$, melakukan penelitian mengenai campuran serbuk aluminium dan gipsum dalam pembuatan bata beton ringan sebagai bahan pengganti parsial semen. 
Rancangan campuran penelitian tersebut menggunakan variasi aluminium sebesar $0 \% ; 0,3 \% ; 0,5 \%$; dan $0,7 \%$ dari berat semen. Pengujian beton dilakukan pada spesimen silinder berukuran diameter 150 $\mathrm{mm}$ dan tinggi $300 \mathrm{~mm}$ saat umur beton 28 hari. Pengujian yang dilakukan mencakup berat jenis beton, serapan air, dan kuat tekan. Pada hasil pengujian ini diperoleh bahwa berat jenis terkecil sebesar 1.946 $\mathrm{kg} / \mathrm{m}^{3}$ dengan menggunakan $0,7 \%$ serbuk aluminium, dan berat jenis terbesar adalah $2.069 \mathrm{~kg} / \mathrm{m}^{3}$ dengan menggunakan $0 \%$ serbuk aluminium. Nilai serapan air terkecil adalah 2,918\% dengan kadar campuran serbuk aluminium sebesar 0\%. Nilai kuat tekan terkecil adalah sebesar 13,599 $\mathrm{MPa}$ dengan kadar serbuk aluminium 0,7\%. Kesimpulan dari penelitian tersebut adalah aluminium dapat mengurangi berat jenis dalam pembuatan beton ringan, tetapi belum mencapai spesifikasi beton ringan yang disyaratkan yaitu $1.800 \mathrm{~kg} / \mathrm{m}^{3}$.

Augustine ${ }^{[7]}$, melakukan penelitian mengenai penggunaan limbah ekstrusi aluminium mentah dalam pembuatan beton normal. Rancangan campuran penelitian tersebut menggunakan variasi aluminium sebesar 5\%; 10\%; 20\%; dan 30\%. Sampel beton yang digunakan pada penelitian ini berbentuk kubus berukuran $150 \mathrm{~mm}$ dan balok berukuran $100 \mathrm{~mm} \times 100 \mathrm{~mm} \times 600$ $\mathrm{mm}$. Pengujian dilakukan saat umur beton 3 hari, 7 hari, 28 hari, 60 hari, dan 90 hari. Pengujian yang dilakukan hanya terhadap kuat tekan dan kuat lentur beton. Hasil pengujian ini menunjukkan bahwa limbah aluminium dapat digunakan sebagai pengganti parsial semen, terlihat dari peningkatan kuat tekan beton dengan penggunaan limbah aluminium antara 5$10 \%$, seperti yang terlihat dari gambar 2 berikut. Penelitian ini juga menyimpulkan bahwa aluminium dapat berfungsi sebagai retarder dan merupakan material yang bagus untuk konstruksi di daerah panas. Pada penelitian yang akan dilakukan, akan digunakan limbah pemotongan aluminium berupa serpihan sebagai substitusi parsial semen dalam campuran beton kekuatan tinggi (high strength concrete). Limbah aluminium yang digunakan merupakan hasil pemotongan aluminium olahan, bukan aluminium murni (Al) seperti pada penelitian Augustine (2011). Selain itu, pengujian yang akan dilakukan pada penelitian ini adalah kuat tekan dan kuat tarik belah beton.

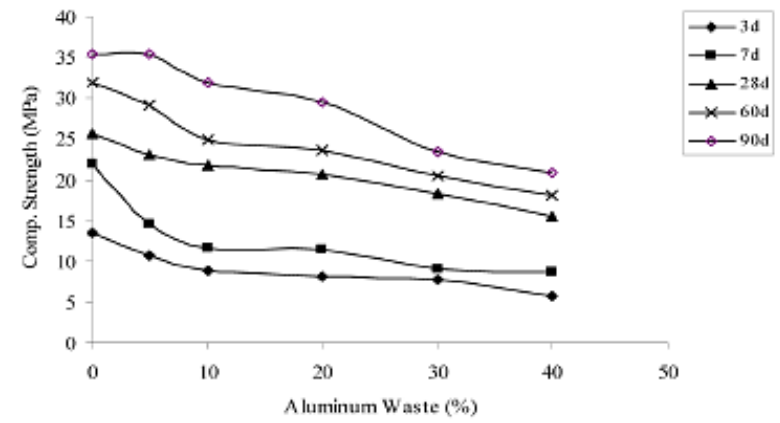

Gambar 1. Hubungan kuat tekan dengan penambahan limbah aluminium

\section{METODOLOGI PENELITIAN Bahan-bahan}

Bahan-bahan yang digunakan dalam penelitian ini adalah:

1. Semen, menggunakan Semen Gresik tipe I

2. Agregat halus, asal Galunggung

3. Agregat kasar, berupa batu pecah ukuran 10 - 20, asal Cigudeg, Bogor

4. Bahan tambahan/additive, berupa superplasticizer, menggunakan produk PT. KAO Indonesia Chemicals, Mighty 21NA-3.

5. Air, berasal dari sumber PDAM

6. Serpihan aluminium, yang berasal dari limbah pemotongan aluminium.

\section{Hasil Uji Agregat}

Agregat yang akan digunakan harus sesuai dengan standar yang digunakan, maka dilakukan pengujian untuk melihat kesesuaian material yang akan dipakai. Hasil uji agregat dapat dilihat pada tabel 3. 
Tabel 3. Sifat Mekanik Agregat

\begin{tabular}{clcc}
\hline $\begin{array}{c}\text { Jenis Agregat } \\
\begin{array}{c}\text { Agregat } \\
\text { Kasar }\end{array}\end{array}$ & \multicolumn{1}{c}{$\begin{array}{c}\text { Jenis Uji } \\
\text { Berat Jenis }\end{array}$} & $\begin{array}{c}\text { Hasil } \\
2,50 \mathrm{gr} / \mathrm{cm}^{3}\end{array}$ & $\begin{array}{c}\text { Syarat } \\
2,2-2,7 \\
\mathrm{gr} / \mathrm{cm}^{3}\end{array}$ \\
\cline { 2 - 4 } & Daya Serap Air & $4,25 \%$ & \\
& Berat Isi & $1,49 \mathrm{~cm}^{3} / \mathrm{gr}$ & $>1,2 \mathrm{gr} / \mathrm{cm}^{3}$ \\
\cline { 2 - 4 } & Kadar Lumpur & $0,85 \%$ & $<1 \%$ \\
\cline { 2 - 4 } Analisa Saringan & 7,81 & $3,0-8,0$ \\
\hline $\begin{array}{c}\text { Agregat } \\
\text { Halus }\end{array}$ & Berat Jenis & $2,51 \mathrm{gr} / \mathrm{cm}^{3}$ & $\begin{array}{c}2,2-2,7 \\
\mathrm{gr} / \mathrm{cm}^{3}\end{array}$ \\
\cline { 2 - 4 } & Daya Serap Air & $5,6 \%$ & \\
& Berat Isi & $1,64 \mathrm{~cm}^{3} / \mathrm{gr}$ & $>1,2 \mathrm{gr} / \mathrm{cm}^{3}$ \\
& Kadar Lumpur & $2,9 \%$ & $<5 \%$ \\
\cline { 2 - 4 } & Analisa Saringan & 2,67 & $1,5-3,8$ \\
\hline
\end{tabular}

Selain uji sifat mekanik, dilakukan juga uji gradasi agregat halus dan agregat kasar, dengan hasil seperti pada gambar 3 dan 4 .

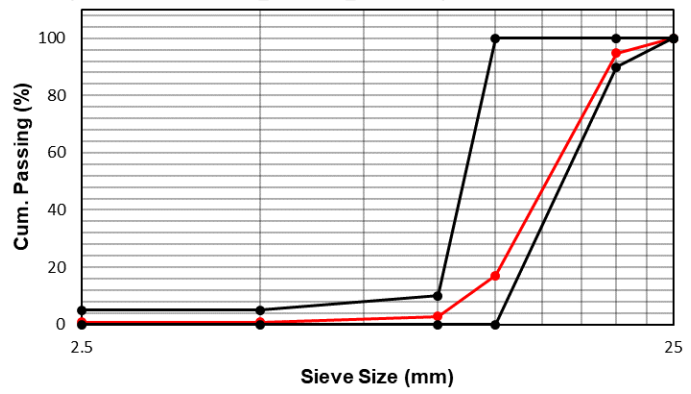

Gambar 3. Grafik analisis saringan agregat kasar

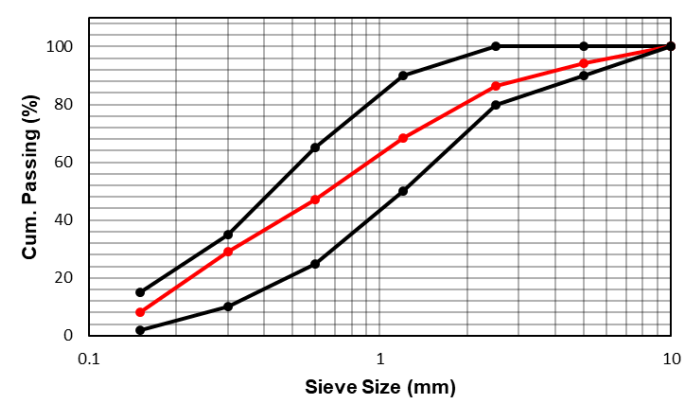

Gambar 4. Grafik analisis saringan agregat halus

\section{Rancangan Campuran}

Berdasarkan hasil uji material yang telah diperoleh dari tabel 2, maka dapat dilakukan perhitungan rancangan campuran beton. Rancangan campuran beton ini dibuat sesuai dengan acuan SNI 03-28342000, tentang Tata Cara Pembuatan Rencana Campuran Beton Normal dan Pedoman T-04-2004-C tentang Tata Cara
Pembuatan dan Pelaksanaan Beton Berkekuatan Tinggi.

Target kuat tekan beton yang disyaratkan $\left(f^{\prime} c\right)$ pada usia beton 28 hari adalah sebesar $45 \mathrm{MPa}$. Pada penelitian ini terdapat 4 jenis komposisi campuran yang akan dibuat, yaitu AL0 untuk campuran beton tanpa bahan parsial, AL5 untuk beton dengan bahan parsial aluminium sebesar $5 \%$, AL7.5 untuk beton dengan bahan parsial aluminium sebesar 7.5\%, dan AL10 dengan bahan parsial aluminium sebesar 10\%. Rancangan campuran beton pada penelitian ini dapat dilihat pada tabel 4 .

\section{Benda Uji}

Untuk mengetahui kuat tekan dan kuat tarik belah beton dari masing-masing campuran beton yang telah dibuat, maka dibuatlah sejumlah benda uji berupa silinder beton berukuran $150 \times 300 \mathrm{~mm}$. Setelah dicetak, beton yang telah mengeras dilepaskan dari cetakan dan diletakkan pada kolam perendaman untuk proses curing.

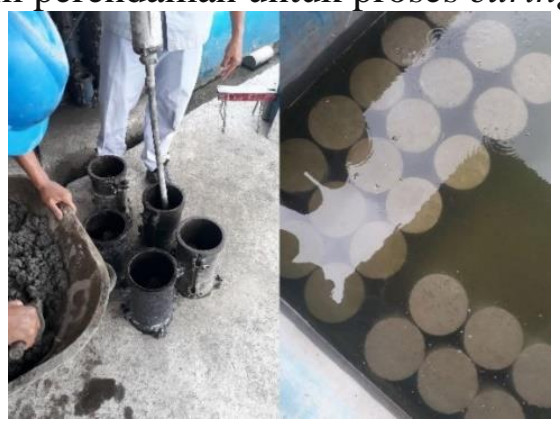

Gambar 5. Proses pencetakan benda uji dan curing 
Metode Uji

Pengujian kuat tekan beton dilakukan sesuai dengan acuan SNI 19742011 tentang Cara Uji Kuat Tekan Beton dengan Benda Uji Silinder, sedangkan untuk kuat tarik belah beton dilakukan sesuai dengan acuan SNI 03-2491-2002 tentang Metode Pengujian Kuat Tarik Belah Beton. Beton diuji dengan universal testing machine (UTM) pada usia benda uji 3, 7, dan 28 hari.

Tabel 4. Komposisi Campuran Beton

\begin{tabular}{cccccccc}
\hline \multirow{2}{*}{$\begin{array}{c}\text { Nama } \\
\text { Sampel }\end{array}$} & $\begin{array}{c}\% \\
\text { Serbuk } \\
\end{array}$ & Air & Semen & $\begin{array}{c}\text { Serbuk } \\
\mathrm{Al}\end{array}$ & $\begin{array}{c}\text { Agregat } \\
\text { Kasar }\end{array}$ & $\begin{array}{c}\text { Agregat } \\
\text { Halus }\end{array}$ & Additive \\
\cline { 3 - 8 } & $\mathrm{kg}$ & $\mathrm{kg}$ & $\mathrm{kg}$ & $\mathrm{kg}$ & $\mathrm{kg}$ & $\mathrm{kg}$ \\
\hline AL0 & 0 & 124,8 & 460 & 0 & 882 & 863,2 & 4,6 \\
\hline AL5 & 5 & 124,8 & 437 & 23 & 882 & 863,2 & 4,6 \\
\hline AL7.5 & 7.5 & 124,8 & 426 & 35 & 882 & 863,2 & 4,6 \\
\hline AL10 & 10 & 124,8 & 414 & 46 & 882 & 863,2 & 4,6 \\
\hline
\end{tabular}

\section{HASIL PENELITIAN DAN ANALISIS Uji Slump}

Pengujian pada beton segar yang dilakukan adalah uji slump untuk mengetahui konsistensi dan kelecakan dari campuran beton. Pada penelitian ini, nilai slump yang ditargetkan adalah sebesar $20 \pm 2 \mathrm{~cm}$. Hasil uji slump dari campurancampuran beton pada penelitian ini dapat dilihat pada tabel 5.

Tabel 5. Hasil Uji Slump

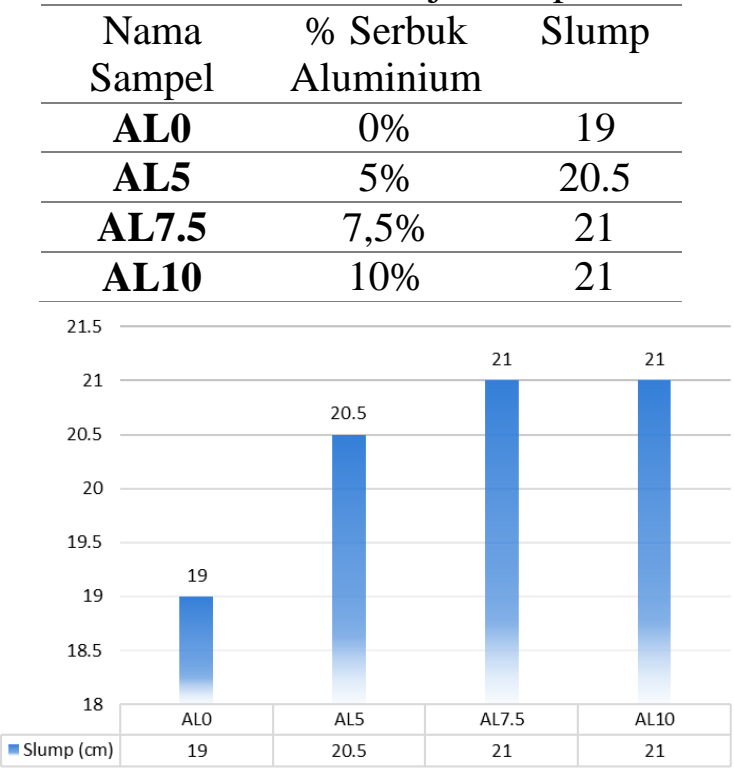

Gambar 6. Grafik hasil nilai slump

Dari grafik diatas, dapat dilihat bahwa semakin besar persentase serbuk aluminium, maka nilai slump menjadi semakin tinggi pula. Nilai slump terendah diperoleh oleh AL0, yaitu sebesar $19 \mathrm{~cm}$. Sedangkan slump tertinggi terjadi pada AL7.5 dan AL10, yaitu $20 \mathrm{~cm}$. Hasil slump ini dipengaruhi oleh dua hal, yaitu karena adanya penambahan superplasticizer dan reaksi kimia yang terjadi antara aluminium dan semen. Dengan adanya superplasticizer dalam campuran beton, maka konsistensi beton semakin cair, sehingga beton akan semakin mudah dikerjakan.

\section{Uji Berat Jenis}

Selain pengujian terhadap kuat tekan dan kuat tarik beton, dilakukan juga penelitian terhadap berat jenis beton. Berat jenis beton pada penelitian ini dapat dilihat pada tabel 6 berikut ini.

Tabel 6. Berat dan Volume Sampel

\begin{tabular}{ccc}
\hline $\begin{array}{c}\text { Nama } \\
\text { Sampel }\end{array}$ & Berat $(\mathrm{kg})$ & $\begin{array}{c}\text { Volume } \\
\left(\mathrm{kg} / \mathrm{m}^{3}\right)\end{array}$ \\
\hline AL0 & 12.6 & 2369.2 \\
\hline AL5 & 10.9 & 2061.4 \\
\hline AL7.5 & 10.3 & 1952.2 \\
\hline AL10 & 10.5 & 1988.2 \\
\hline
\end{tabular}

Berat jenis beton dapat diperoleh dengan membagi berat sampel beton terhadap volume sampel beton. Beton dengan bahan parsial aluminium memiliki nilai berat jenis lebih rendah daripada beton normal. Berat jenis terendah dicapai oleh AL7.5 dengan bahan parsial serbuk 
aluminium sebanyak $7.5 \%$, yaitu 1952,2 $\mathrm{kg} / \mathrm{m}^{3}$.

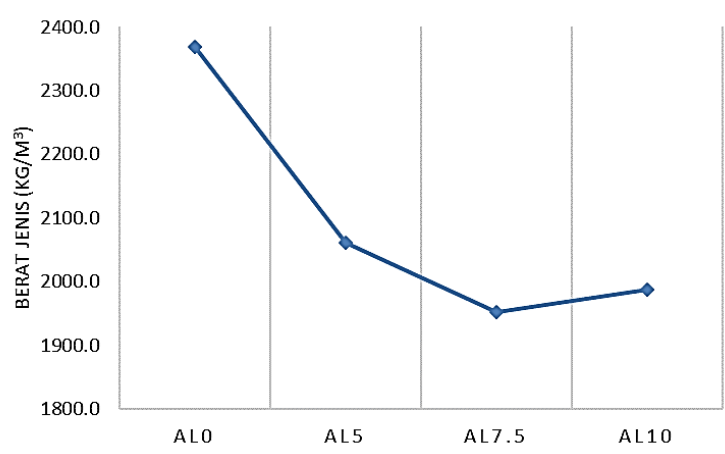

Gambar 7. Grafik berat jenis beton

Dilihat dari grafik pada gambar 7 , berat jenis beton terus menurun seiring bertambah banyaknya serbuk aluminium. Tetapi pada AL10, berat jenis sedikit meningkat, namun perbedaan dengan AL7.5 tidak terlalu signifikan. Berat jenis beton dengan bahan parsial serbuk aluminium ini belum termasuk pada kategori beton ringan, karena berat jenisnya tidak kurang dari $1900 \mathrm{~kg} / \mathrm{m}^{3}$.

\section{Uji Kuat Tekan}

Hasil uji kuat tekan beton dapat dilihat pada tabel 7 dan grafik persentase kuat tekan dapat dilihat pada gambar 8 .

Tabel 7. Hasil Uji Kuat Tekan Beton

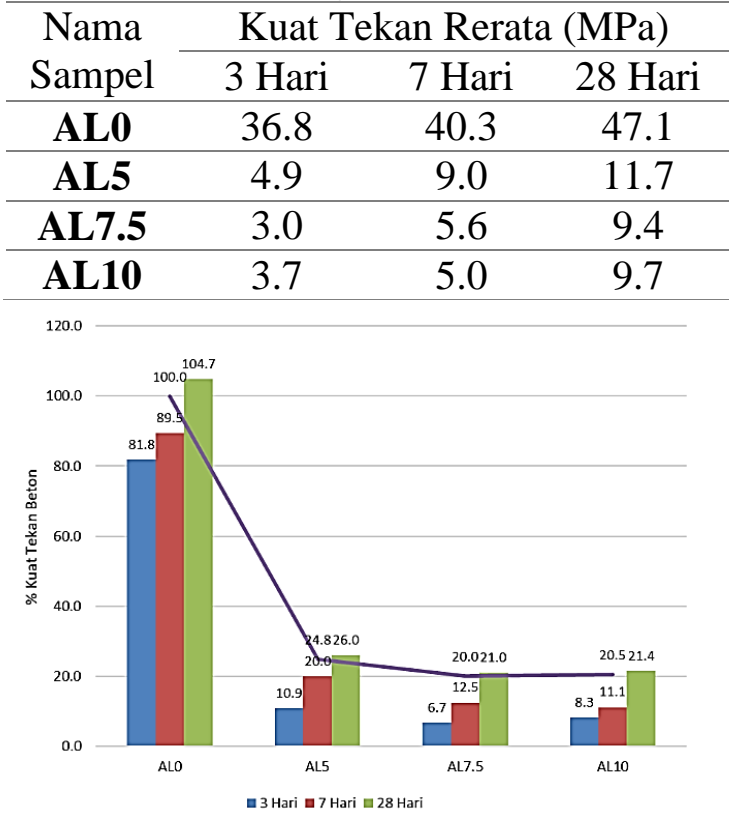

Gambar 8. Grafik persentase kuat tekan beton
Dari grafik diatas, dapat dilihat bahwa kuat tekan untuk sampel beton normal atau AL0 secara keseluruhan mencapai standar kuat tekan yang disyaratkan. Sedangkan untuk sampel yang ditambahkan dengan serbuk aluminium, semuanya berada dibawah standar. Pada usia 3 hari, ketiga sampel yaitu AL5, AL7.5, dan AL10 tidak mencapai 40\% kuat tekan yang direncanakan. Pada campuran beton dengan penambahan serbuk aluminium sebanyak $7.5 \%$, terlihat adanya penurunan kuat tekan sampai $80 \%$, dimana nilai kuat tekan pada sampel AL7.5 adalah kuat tekan terkecil dibandingan dengan campuran lainnya.

Faktor utama yang menyebabkan menurunnya kuat tekan beton yang ditambahkan serbuk aluminium adalah karena reaksi kimia yang terjadi antara aluminium dengan beton. Reaksi kimia yang terjadi menghasilkan gas hidrogen, yang kemudian menyebabkan adanya gelembung-gelembung udara pada sampel. Setelah beton mengering, gelembung udara tersebut juga menguap dan menghasilkan rongga-rongga pada beton. Rongga udara menyebabkan menurunnya kuat tekan beton, karena beton yang dihasilkan menjadi tidak padat.

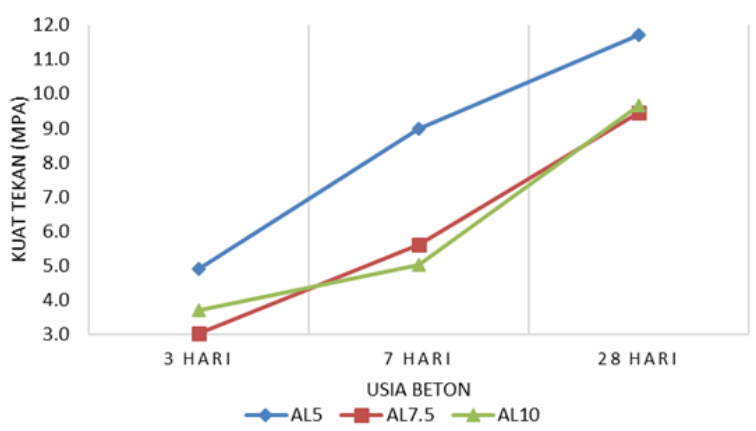

Gambar 9. Grafik pertumbuhan kuat tekan beton aluminium

Bila kuat tekan beton aluminium dibandingkan, nilai kuat tekan tertinggi dicapai oleh AL5 dengan bahan parsial serbuk aluminium sebanyak 5\%, yaitu sebesar 11,7 MPa. Kuat tekan beton terendah dicapai oleh AL7,5 dengan bahan parsial serbuk aluminium sebanyak 7,5\%, yaitu sebesar 9,4 MPa. 
Faktor lain yang mempengaruhi kuat tekan beton, adalah beton dengan bahan parsial aluminium masih belum sepenuhnya kering ketika diuji, walaupun sudah dijemur selama hampir 3 hari. Hal ini dikarenakan adanya rongga-rongga pada badan beton, sehingga proses pengeringan membutuhkan waktu lama.

\section{Uji Kuat Tarik Belah}

Hasil uji kuat tarik belah dapat dilihat pada tabel 7 , sedangkan untuk grafik pertumbuhannya dapat dilihat pada gambar 10.

Tabel 8. Hasil Uji Kuat Tarik Belah Beton

\begin{tabular}{cccc}
\hline $\begin{array}{c}\text { Nama } \\
\text { Sampel }\end{array}$ & \multicolumn{3}{c}{$\begin{array}{c}\text { Kuat Tarik Belah Rerata } \\
(\mathrm{MPa})\end{array}$} \\
\cline { 2 - 4 } & 3 Hari & 7 Hari & 28 Hari \\
\hline AL0 & 2.3 & 2.5 & 4.3 \\
\hline AL5 & 1.0 & 1.2 & 1.9 \\
\hline AL7.5 & 0.3 & 0.7 & 1.8 \\
\hline AL10 & 0.8 & 0.8 & 1.5
\end{tabular}

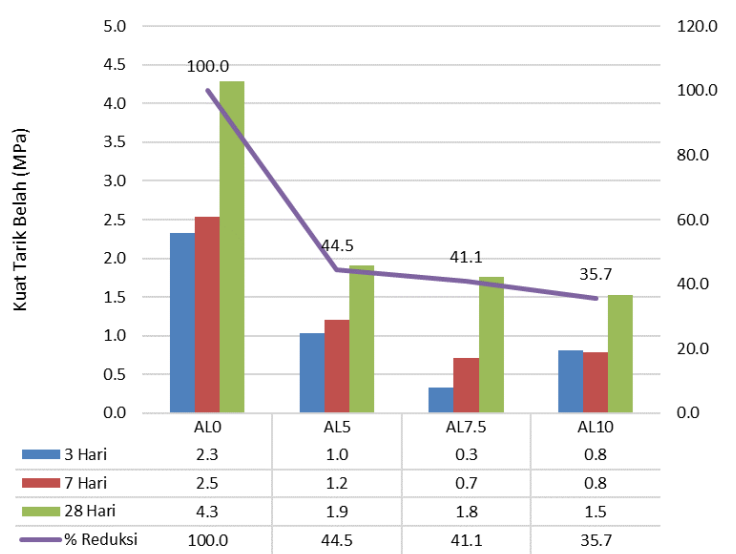

Gambar 10. Grafik persentase kuat tarik beton

Grafik diatas menunjukkan perbandingan nilai kuat tarik belah beton pada masing-masing campuran beton. Dapat dilihat bahwa kuat tarik beton tertinggi dicapai oleh AL0, yaitu campuran beton tanpa serbuk aluminium, sebesar 4.3 $\mathrm{MPa}$. Kuat tekan beton dengan campuran serbuk aluminium memiliki kecenderungan terjadinya penurunan, sama seperti pada kuat tekan beton. Kuat tarik belah beton mengalami penurunan hingga $64,3 \%$ pada sampel AL10, dimana nilai kuat tarik AL10 adalah sebesar 1.5 MPa.

Pada beton dengan bahan parsial serbuk aluminium, kuat tarik belah paling tinggi dicapai oleh AL5, yaitu sebesar 1.9 $\mathrm{MPa}$ dengan bahan parsial serbuk aluminium sebanyak 5\%. Sedangkan untuk kuat tarik belah yang paling rendah dicapai oleh AL10, yaitu sebesar 1.5 MPa dengan bahan parsial serbuk aluminium sebanyak $10 \%$.

Faktor yang mempengaruhi kuat tarik belah beton adalah kurangnya pengikatan antara pasta semen dengan agregat, karena pasta semen kehilangan zat kimia untuk mengikat, sehingga beton lebih mudah pecah.

Sesuai dengan ACI 318 tentang Building Code Requirement for Structural Concrete, hubungan kuat tarik belah beton dengan kuat tekan beton dapat dihitung dengan menggunakan persamaan 3 . Sehingga, pada penelitian ini, dapat dibandingkan nilai kuat tarik secara aktual dan secara empiris. Perbandingan nilai kuat tarik aktual dan empiris tersebut dapat dilihat pada tabel 9 berikut.

Tabel 9. Perbandingan Kuat Tarik Aktual dan Empiris

\begin{tabular}{cccc}
\hline Nama & \multirow{2}{*}{$\begin{array}{c}\text { Kuat } \\
\text { Sampel }\end{array}$} & $\begin{array}{c}\text { Kekan } \\
\text { Rerata }\end{array}$ & \multicolumn{2}{c}{\begin{tabular}{c} 
Rerata $(\mathrm{MPa})$ \\
\cline { 3 - 4 }
\end{tabular}} & $\begin{array}{c}\text { Aktual } \\
(\mathrm{MPa})\end{array}$ & Empiris \\
\hline AL0 & 47.1 & 4.3 & 3.8 \\
\hline AL5 & 11.7 & 1.9 & 1.9 \\
\hline AL7.5 & 9.4 & 1.8 & 1.7 \\
\hline AL10 & 9.7 & 1.5 & 1.7 \\
\hline
\end{tabular}

Dapat dilihat pada Gambar 11, kuat tarik belah aktual nilainya tidak jauh berbeda dengan kuat tarik yang dihitung secara empiris, dimana rumus tersebut digunakan untuk estimasi nilai kuat tarik belah. Perhitungan regresi juga menunjukkan bahwa perbedaan antara nilai kuat tarik belah aktual dan empiris tidak jauh berbeda. Dari grafik tersebut diketahui nilai regresi untuk kuat tarik aktual adalah 
$\mathrm{R}^{2}=0.7185$, sedangkan nilai regresi untuk kuat tarik empiris adalah $\mathrm{R}^{2}=0.6638$.

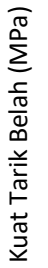

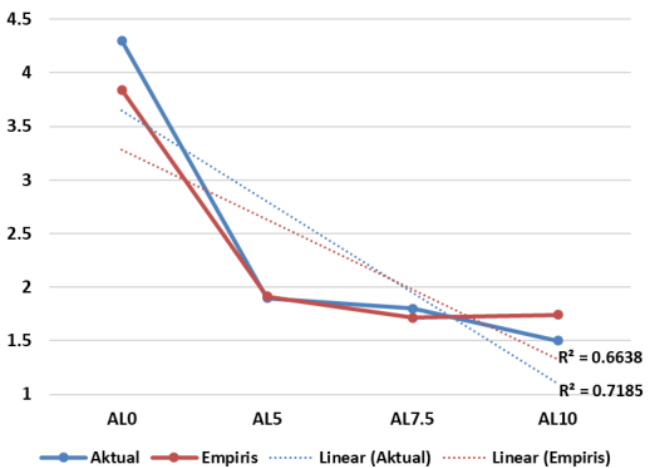

Gambar 11. Grafik perbandingan kuat tarik belah aktual dan empiris

\section{KESIMPULAN}

Berdasarkan hasil pengujian, maka diperoleh beberapa kesimpulan, yaitu:

1. Munculnya gelembung-gelembung udara pada beton segar akibat reaksi kimia antara serbuk aluminium dengan semen. Gelembung-gelembung udara ini berubah menjadi rongga-rongga ketika beton mengering, sehingga mempengaruhi sifat-sifat mekanis beton.

2. Menurunnya berat jenis beton seiring bertambahnya jumlah serbuk aluminium. Berat jenis beton normal berkisar $2400 \mathrm{~kg} / \mathrm{m}^{3}$, dimana pada penelitian ini sampel beton normal (AL0) memiliki berat jenis sebesar $2369,2 \mathrm{~kg} / \mathrm{m}^{3}$. Berat jenis beton paling rendah diperoleh oleh sampel beton AL7.5 yaitu sebesar 1952,2 $\mathrm{kg} / \mathrm{m}^{3}$. Tetapi berat jenis beton AL7.5 belum memenuhi kategori beton ringan yang sebesar $\leq 1900 \mathrm{~kg} / \mathrm{m}^{3}$.

3. Kuat tekan beton normal (AL0) adalah sebesar 47,1 MPa, dimana melebihi kuat tekan rencana yang sebesar $45 \mathrm{MPa}$. Kuat tekan dengan penambahan parsial serbuk aluminium secara keseluruhan tidak ada yang mencapai kuat tekan rencana. Kuat tekan dengan parsial serbuk aluminium tertinggi dicapai oleh sampel beton AL5 dengan penambahan parsial serbuk aluminium sebanyak 5\%, yaitu sebesar 11,7 MPa. Dengan hasil kuat tekan tersebut, maka beton aluminium belum bisa digunakan sebagai beton struktur dengan syarat minimum kuat tekan sebesar $20 \mathrm{MPa}$.

4. Kuat tarik beton normal (AL0) diperoleh sebesar 4.3 MPa, dimana menjadi kuat tarik tertinggi dari seluruh sampel. Kuat tarik belah beton tertinggi pada beton aluminium diperoleh oleh AL5 dengan penambahan parsial serbuk aluminium sebanyak 5\%, yaitu sebesar 6,0 MPa. Seluruh nilai kuat tarik belah aktual bila dibandingkan dengan nilai kuat tarik secara empiris nilainya kurang lebih sama.

5. Nilai optimum penggunaan serbuk aluminium terdapat pada sampel AL5, dimana hasil pengujian baik kuat tekan atau pun kuat tarik, menunjukkan hasil yang lebih baik daripada sampel AL7.5 dan AL10.

6. Penurunan nilai kuat tekan dan kuat tarik belah pada beton yang ditambahkan serbuk aluminium terjadi karena berkurangnya zat kimia yang berfungsi untuk mengikat seperti kalsium (Ca).

\section{DAFTAR PUSTAKA}

1. American Concrete Institute, ACI 31899, Building Code Requirements for Structural Concrete, 1999.

2. Badan Standarisasi Nasional, SNI 032834-2000, Tata Cara Pembuatan Rencana Campuran Beton Normal, 2000.

3. Badan Standarisasi Nasional, SNI 1974:2011, Cara Uji Kuat Tekan Beton Dengan Benda Uji Silinder, 2011.

4. Badan Standarisasi Nasional, SNI 032491-2000, Metode Pengujian Kuat Tarik Belah Beton, 2002. 
5. Elinwa, Augustine U., dan Mbadike, E., The Use of Aluminum Waste for Concrete Production, Journal of Asian Architecture and Building Engineering, 220, pp. 217 - 220, 2011.

6. University of Babylon, Chemical Composition of Cement, http://www.uobabylon.edu.iq/eprints/p ublication_1_302_1586.pdf, diakses pada 25 September 2017.

7. Zainudin, A., Pengaruh Variasi Campuran Serbuk Aluminium Dalam Pembuatan Bata Beton Ringan Dengan Bahan Tambah Serbuk Gipsum, Skripsi Program Sarjana, Universitas Muhammadiyah Surakarta, 2014, diunduh dari http://eprints.ums.ac.id/32147/17/Nas kah\%20Publikasi.pdf, diunduh pada tanggal 23 September 2017. 